University of Nebraska - Lincoln

DigitalCommons@University of Nebraska - Lincoln

USDA Wildlife Services - Staff Publications

U.S. Department of Agriculture: Animal and Plant Health Inspection Service

$7-2021$

\title{
Testing a Bite-Shortened Hook to Minimize Fish Handling in a Recreational Fishery
}

\author{
Holden E. Harris \\ University of Florida \\ Brian K. Whalen \\ U.S. Department of Agriculture \\ Andrew G. Gude \\ U.S. Fish and Wildlife Service \\ Michael S. Allen \\ University of Florida
}

Follow this and additional works at: https://digitalcommons.unl.edu/icwdm_usdanwrc

Part of the Natural Resources and Conservation Commons, Natural Resources Management and Policy Commons, Other Environmental Sciences Commons, Other Veterinary Medicine Commons, Population Biology Commons, Terrestrial and Aquatic Ecology Commons, Veterinary Infectious Diseases Commons, Veterinary Microbiology and Immunobiology Commons, Veterinary Preventive Medicine, Epidemiology, and Public Health Commons, and the Zoology Commons

Harris, Holden E.; Whalen, Brian K.; Gude, Andrew G.; and Allen, Michael S., "Testing a Bite-Shortened Hook to Minimize Fish Handling in a Recreational Fishery" (2021). USDA Wildlife Services - Staff Publications. 2525.

https://digitalcommons.unl.edu/icwdm_usdanwrc/2525

This Article is brought to you for free and open access by the U.S. Department of Agriculture: Animal and Plant Health Inspection Service at DigitalCommons@University of Nebraska - Lincoln. It has been accepted for inclusion in USDA Wildlife Services - Staff Publications by an authorized administrator of DigitalCommons@University of Nebraska - Lincoln. 
Discard mortality can make fishing unsustainable, even in catch-and-release or highly regulated fisheries. However, fishing practices and gears that minimize hook injury, handling, and air exposure can considerably improve fitness and survival in released fish. This study tested whether modified hooks could allow anglers to successfully land and then release fish in the water and without handling. Standard, barbless, and bite-shortened hooks were used to catch Spotted Seatrout Cynoscion nebulosus ( $\mathrm{n}>75$ per hook type), and logistic models were used to assess the differences in landing success and hook self-release success by hook type and categorical fish size. Average landing success was $>90 \%$ with all three hook types. Bite-shortened hooks were able to successfully self-release from $87 \%$ of landed fish, compared to success rates of $47 \%$ using barbless hooks and $20 \%$ using standard hooks. Small fish had higher rates of both unintentional release during reel-in and intentional handling-free release boatside. Size selectivity by hook type was not observed. Continued gear testing of bite-shortened hooks appears warranted with other lure types, fish species, and a diversity of anglers. With further validation, self-releasing hooks could allow for recreational fishing opportunities in sensitive fisheries or areas, e.g., no-take aquatic reserves, with minimal discard effects.

\section{INTRODUCTION}

Releasing fish can help conserve fishery resources by reducing harvest mortality. However, the process of capturing and handling fish can result in reduced fitness or death (Davis 2002; Arlinghaus et al. 2007; Cooke and Schramm 2007) from physiological stress, injuries, and mortalities that are generally cryptic in discarded fish (Coggins et al. 2007; Raby et al. 2013; Bohaboy et al. 2019). Cumulatively, discard effects present a major conservation issue in recreational fisheries - for both catch-and-release fishing as well as highly regulated consumption fishing - where large numbers of fish are released (Davis 2002; Cooke and Cowx 2004; Pollock and Pine 2007). Fish contact with hands and fishing nets can cause internal organ damage (Danylchuk et al. 2008; Brownscombe et al. 2017) and disrupt the epidermal mucus membrane (Colotelo and Cooke 2011; Hannan et al. 2015), which increases infection risk and predation (Kostecki et al. 1987; Barthel et al. 2003). Further injury is likely if anglers handle and dehook the fish out of the water. Air exposure and asphyxiation immediately following the cardiac and respiratory stress a fish experiences during retrieval can cause low arterial oxygen saturation, severe anoxia, and collapsed gill lamellae (Ferguson and Tufts 1992; Cook et al. 2015) that can cause permanent tissue damage, reduced long-term fitness, and mortality from injury or predation (Cooke et al. 2013). With increasing scientific understanding of these processes, outreach campaigns and modern messaging products encourage anglers to minimize handling and to keep fish in the water (Danylchuk et al. 2018). Adoption of these best fishing practices can considerably improve the outcome of released fish by minimizing injury with certain hooks, not contacting fish with dry surfaces, and limiting fish handling and air exposure (reviewed in Cooke and Suski 2005 and Brownscombe et al. 2017). Given the continuing increase of recreational fishing activity, widespread adoption of practices that minimize handling stress in released fish can assist global conservation of fisheries resources (Cooke and Cowx 2004; Brownscombe et al. 2017).

Efficient dehooking substantially reduces the physiological stress in fish that typically occurs during the landing and release process (Cooke et al. 2001; Cooke and Schramm 2007; Brownscombe et al. 2017). The type of hook, in particular, can affect the severity of injury and likelihood of mortality in released fish (Muoneke and Childress 1994; Cooke et al. 2001; Cooke and Suski 2005). For example, the mandated use of non-offset circle hooks has decreased traumatic hooking mortalities $>50 \%$ in some of the Gulf of Mexico's most important reef fish fisheries (Sauls and Ayala 2012; Garner et al. 2017). Use of non-offset circle hooks has similarly decreased fish injury for freshwater gamefish such as Largemouth Bass Micropterus salmoides, while also increasing capture efficiency
(Ostrand et al. 2005). However, it is not always certain whether gear modifications will be accepted by anglers (Bartholomew and Bohnsack 2005; Cooke et al. 2006). Voluntary or mandatory use of barbless hooks is encouraged in many catch-andrelease fisheries, based on evidence that they reduce fish injury and dehooking time (Muoneke and Childress 1994; Cooke et al. 2001; Cooke and Suski 2005); although contradictory results have also indicated that barbless hooks had no discernable effect on discard mortality but instead lowered capture efficiency, and that these lower capture rates could decrease angler satisfaction (Butler and Loeffel 1972; Schaeffer and Hoffman 2002; Bloom 2013). The effectiveness of modified hooks to mitigate discard effects, as well as the willingness for anglers to adopt new gears and practices, will ultimately vary between individual fish species and the behavior of anglers in that fishery.

Here we examine the potential for hook modifications to allow anglers to land and handling-free release a popular coastal sport fish, Spotted Seatrout Cynoscion nebulosus. Our testing of self-releasing hooks was conducted as a follow-up and more rigorous study of initial field trials with modified hooks used for catch-and-release angling in a U.S. National Wildlife Refuge (Gude et al. 2012). To our knowledge, these are the first assessments of hooks designed to self-release from fish and fully eliminate fish handling. Three candidate hook designs - standard, barbless, or bite-shorted hooks (Figure 1) - were tested on their ability to land the fish (i.e., the angler successfully retrieves the Spotted Seatrout to the boatside) and then self-release from the fish (i.e., the fish is intentionally released boatside without any handling by the angler). The potential for size selectivity by hook type was also assessed, as well as the effect of fish size on landing success and the hook's self-release success. Based on our findings, we consider future research directions and management applications for self-releasing hooks to offer a quality angling experience, while minimizing lethal and sublethal discard effects from catch-and-release fishing.

\section{METHODS}

Gear testing compared the use of a standard (i.e., unmodified) hook against hooks modified to be barbless or biteshortened (Figure 1). Standard hooks were $3.5 \mathrm{~g}(1 / 8 \mathrm{oz})$ jigheads (Offshore Angler Deluxe Standup) with a 15-mm bite distance (i.e., the horizontal distance between the hook point and apex of the metal bend) and had a backward facing barb. Barbless hooks were made from the standard hooks using a dermal grinder (i.e., a Dremel tool) to remove the barb. Bite-shortened hooks were made from standard hooks by cutting off the barbed portion of the hook with wire cutters to shorten the bite distance to $10 \mathrm{~mm}$, and then sharpening the 
(A) Standard hook

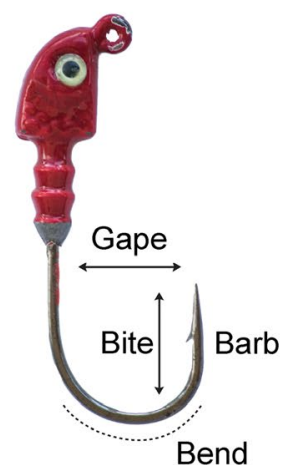

(B) Barbless hook

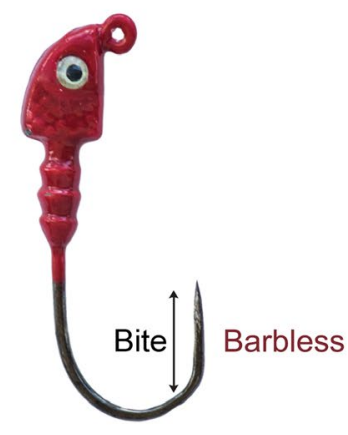

(C) Bite-shortened

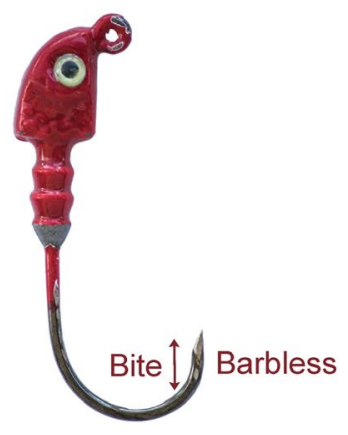

Figure 1. Photographs with labels for standard, barbless, and bite-shortened hook designs tested for their ability to land and be self-released from Spotted Seatrout. (A) The unmodified jighead "standard" hook had a 15-mm bite distance and backward facing barb. (B) The barb on a standard hook was removed to make the "barbless" modified hook, with no other changes made. (C) "Bite-shortened" modified hooks were made by reducing the bite length of a barbless hook to 10-mm, which also removed the barb. The curvature in the hook bend and the gape distance were the same for all three hook types.

end at the cut-off point with the dermal grinder. A short video demonstrating this procedure to modify a standard hook to a bite-shortened hook is available: https://bit.ly/3z9nRCb. The gape distance and hook bend in the modified hooks were unchanged from the standard hook (Figure 1).

Data were collected for each of the three hook types using catch-and-release angling for Spotted Seatrout. Angling was conducted during daylight hours from June-August in 2018 on seagrass habitats in depths 1-6 m near Cedar Key, Florida $\left(\sim 29.1^{\circ} \mathrm{N}, 83.0^{\circ} \mathrm{W}\right)$. Angling was conducted by two individuals (B. Whalen and J. Procopio) using a cast-jig-retrieve method. Both anglers were relatively experienced in saltwater fishing, but neither angler had any prior experience using barbless hooks, bite-shortened hooks, nor any other selfreleasing hook. Hook types were changed every 30 minutes and different hook types were used to start each day of data collection. Fishing gear consisted of spinning rods $(2.1 \mathrm{~m}$, medium-light, fast-action) and reels rigged with $7-\mathrm{kg}$ braided spectra fiber micro filament line. A 9-kg test fluorocarbon leader was joined to the hook with a non-slip Kreh loop knot tied with three wraps around the standing section. All three hook types were baited with artificial shrimp lures $(76 \mathrm{~mm}$ / 3 inches in length). The anglers had a state of Florida Saltwater fishing license and no special permits were needed to perform this work. Humane live fish sampling protocols were reviewed and approved by the University of Florida's Institutional Animal Care and Use Committee (UFIACUC Protocol \#201809219).

Catch data were recorded for binary success of landing the given fish boatside ("landing success"), binary success of the hook self-releasing from landed fish without handling ("hook self-release success"), and categorical fish size (if landed). Landing success was determined as whether the hooked fish was retrieved to within $1 \mathrm{~m}$ of the boat gunnel, i.e., where an angler would normally handle the fish to remove the hook. Analyses excluded any fish hooked and landed that were not Spotted Seatrout, which included Ladyfish Elops saurus and Channel Catfish Ictalurus punctatus. Fish in our dataset that were lost during retrieval (i.e., failed landings; $n=11$ total) were assumed to be Spotted Seatrout based on the angler's qualitative assessment of the habitat, bite, and fighting style. Estimated fish size was visually categorized as "small" ( $\leq 330 \mathrm{~mm}, \leq 13$ inches) or "large" (>330 mm, >13 inches).
Once the fish was landed, the angler would attempt to allow the fish to release itself from the hook by gently raising the rod tip to lift the fish into a head-up position and then lowering the rod tip to give slack in the line. The angler would then keep the rod lowered without tension in the line and count out loud to approximate 10 seconds. This same sequence of events to allow for a potential handling-free release was followed for all hook types. A short video showing the hook successfully self-releasing in slow motion is available: https://bit.ly/3xPq9X1. A short video of an unsuccessful self-release is available: https://bit.ly/3BldNbx. In the video showing the unsuccessful self-release, tension is not released in the line and the fish is unable to disengage itself from the hook. Fish were released by hand if it failed to selfrelease from the hook after approximately 10 seconds. Data collection continued until $>75$ fish were hooked with each hook type.

Success rates that fish were landed boatside (Equation 1) and that the hook self-released (Equation 2) were assessed with logistic regressions computed with logit-linked generalized linear models (GLMs). The full form (hook type $\times$ fish size) for each GLM included the effects of hook type (categorical with three levels: standard, barbless, or bite-shortened), fish size (categorical with two levels: small or large), and the interaction of hook type : fish size. The full model was compared to simpler models that included both effects but without the interaction (i.e., hook type + fish size), single effects of hook type only or fish size only, and no effect (the null model). Multimodel inference and selection considered fit and parsimony with Akaike information criterion (AIC) of each model's penalized log-likelihood (Akaike 1974; Dunn and Smyth 2018) with significantly different models determined with a $\triangle \mathrm{AIC}>2$ (Burnham 2002). Confidence intervals around the means were estimated by generating predicted probabilities with the selected models (Bolker 2007). To test whether size categories differed between the three hook types, contingency tables of size classes were produced and a Pearson's chi-squared $\left(\chi^{2}\right)$ statistic was used to test for significant differences $(P<0.05)$ in the expected versus observed size-class frequencies between the three hook types. All models and analyses were conducted in $\mathrm{R}$ version 4.0.4 ( $\mathrm{R}$ Core Team 2021) with GLMs computed using the LME4 package (Bates et al. 2015). All data and R code for producing the analyses and figures are included in the supplementary materials. 
Landed boatside $\sim \operatorname{Binomial}(\mu) \operatorname{logit}(\mu)=$ hook type +fish size + hook type: fish size

Eq. 1

$$
\begin{aligned}
& \text { Hook self released } \sim \operatorname{Binomial}(\mu) \operatorname{logit}(\mu)= \\
& \text { hook type }+ \text { fish size }+ \text { hook type: fish size }
\end{aligned}
$$

\section{RESULTS}

A total of 226 Spotted Seatrout were hooked (75 with standard hooks, 75 with barbless hooks, and 76 with biteshortened hooks). Ninety-five percent (215 fish) of the hooked fish were successfully landed boatside and 51\% (109 fish) of those landed were able be released without handling (Table 1). Mean landing success for the standard, barbless, and biteshortened hooks was 99\%, 96\%, and 91\%, respectively. Fish sizes included 69 small and 144 large fish. It should be noted that 13 of the landed fish (12 with bite-shortened hook and 1 with the barbless hook) were unintentionally released (lost) prior to landing and before a visual size estimate could be confidently taken. The 11 fish lost before landing were assumed to be Spotted Seatrout, based on our angling experience during this study, but were not visually confirmed.

Landing success was affected by fish size. Model selection indicated the best fit GLMs were fish size and fish size + hook type $(\triangle \mathrm{AIC}=1$; Table 2$)$. Results from both models estimated landing success to be approximately 14-times higher for large fish across the three hook types (Table 3). Differences between mean landing success among the hook type levels were not statistically significant (Table 3); however, it is notable that biteshortened hooks had a 10\% lower landing success for small fish compared to the standard hook (Figure 2A). A lack of size selectivity among the hook types was indicated by the chi-square test results, which found that size-class frequencies were not significantly different from the expected frequency among hook types $\left(\chi^{2}=0.995, d f=2, P=0.608\right)$.

Hook self-release success was strongly affected by hook type and, to lesser extent, fish size. Bite-shortened hooks were the best performing hook with an $87 \%$ mean self-release success rate, compared to $20 \%$ and $47 \%$ for standard and barbless hooks, respectively. The best fit model for hook self-release success included hook type and fish size without the interaction term (Table 2). The GLM results estimated that, compared to the standard hook, the odds of achieving a successful handling-free release was approximately 4-times higher with the barbless hook and 25-times higher with the bite-shortened hook (Table 3 ). Fish size also had a significant but considerably smaller effect (Table 3), with small fish consistently self-released at higher rates than larger fish (a difference of $7-15 \%$ ) across all three hook types (Table 1; Figure 2B).

\section{DISCUSSION}

A proven and effective self-releasing hook gear could have broad conservation and management applications as a means to minimize or eliminate discard effects from the trauma caused by dehooking, contact with hands and fishing nets, and air exposure (Bartholomew and Bohnsack 2005; Cooke and Suski 2005; Brownscombe et al. 2017). In this study, the bite-shortened modified hooks allowed anglers to land $91 \%$ of hooked Spotted Seatrout and then release $87 \%$ of those fish without direct handling. In comparison, the standard and barbless hooks had similar landing success rates $(99 \%$ and $96 \%$, respectively), but their hook self-release success rates were considerably lower (20\% and $47 \%$, respectively). Further investigation could examine the potential use of selfreleasing hooks in recreational fisheries where a management goal is to allow angler access, while keeping catch-and-release fishing impacts fishing to a minimum. Wide-scale use may be encouraged by our demonstrations that the bite-shortened modification can easily be made using simple tools and that size-selectivity was not observed between the different hook types. Continued study appears warranted as the potential efficacy and application of self-releasing hooks will depend on whether the results here could be replicated with different fishes, lures, and anglers.

Small fish were more likely to become unhooked during reel-in (i.e., unintentionally released) and also be handling-free released (intended hook self-release) than large fish. The cause for this may be that larger individuals have larger gape sizes (Nilsson and Brönmark 2000), which may make them more likely to be hooked deeper and thus more difficult for the hook to self-release. Larger fish size has shown to correlate with higher incidences of deep and traumatic hooking for Northern Pike Esox Lucius (Stalhammar et al. 2014), Gulf of Mexico reef fishes (Garner et al. 2017), and western Mediterranean coastal fishes (Cerdà et al. 2010). Regardless of the mechanism, higher hook self-release rates of smaller fish would be desirable for Spotted Seatrout and other length-regulated fisheries as a means to protect younger, faster-growing fish and preclude growth overfishing (Allen et al. 2013; Prince and Hordyk 2019; Ahrens et al. 2020). These results also suggest that landing success will likely vary in different species due to differences in fish size and mouth morphologies. Fighting behaviors that release tension on the hook, e.g., by swimming towards the angler or by jumping, would likely cause a bite-shortened hook to unintentionally release from a fish before it is landed. Different lure

Table 1. Numbers of hooked, landed, and handling-free released Spotted Seatrout used to estimate binomial landing success and hook selfrelease success based on hook type and fish size. Percentages indicate the proportion of hooked fish that were landed and the proportion of

\begin{tabular}{|c|c|c|c|c|}
\hline Hook type & Fish size category & Hooked & Landed & $\begin{array}{c}\text { Hook } \\
\text { self-released }\end{array}$ \\
\hline \multirow[t]{2}{*}{ Standard } & Small & 27 & $26(96 \%)$ & $8(31 \%)$ \\
\hline & Large & 48 & $48(100 \%)$ & $7(15 \%)$ \\
\hline \multirow[t]{2}{*}{ Barbless } & Small & 21 & $19(90 \%)$ & $11(58 \%)$ \\
\hline & Large & 53 & $53(100 \%)$ & $23(43 \%)$ \\
\hline \multirow[t]{2}{*}{ Bite-shortened } & Small & 21 & $18(86 \%)$ & $18(89 \%)$ \\
\hline & Large & 43 & $42(98 \%)$ & $35(83 \%)$ \\
\hline
\end{tabular}
landed fish where the hook self-released. 
Table 2. Akaike information criteria (AIC) scores for binomial generalized linear models to assess landing success and hook selfrelease release success of Spotted Seatrout, including degrees of freedom (df) and delta AIC from the best supported model. Model effects include categorical fish size (small $\leq 330 \mathrm{~mm}$ or large $>330 \mathrm{~mm}$ ) and hook type (standard, barbless, or bite-shortened). The full model (fish size $\times$ hook type) includes both effects and their interaction.

\begin{tabular}{|c|c|c|c|c|c|}
\hline \multirow{2}{*}{$\begin{array}{l}\text { Model } \\
\text { effects }\end{array}$} & \multirow[b]{2}{*}{ df } & \multicolumn{2}{|c|}{ Landing success } & \multicolumn{2}{|c|}{$\begin{array}{c}\text { Hook self-release } \\
\text { success }\end{array}$} \\
\hline & & AIC & $\Delta \mathrm{AIC}$ & AIC & $\Delta \mathrm{AIC}$ \\
\hline Null & 1 & 90.0 & 33.3 & 300.0 & 70.2 \\
\hline Fish size & 2 & 56.7 & - & 291.5 & 61.6 \\
\hline Hook type & 3 & 88.5 & 31.8 & 233.6 & 3.8 \\
\hline $\begin{array}{l}\text { Hook type + } \\
\text { fish size }\end{array}$ & 4 & 57.8 & 1.1 & 229.9 & - \\
\hline $\begin{array}{l}\text { Hook type } \times \\
\text { fish size }\end{array}$ & 6 & 60.5 & 3.8 & 233.6 & 3.7 \\
\hline
\end{tabular}

types may alter success rates in Spotted Seatrout or other species, considering that lure type and lure size can affect hooking location (Wilde et al. 2003; Alós et al. 2008; Stalhammar et al. 2014). Prescriptive use of hook size for contact selectivity may also allow for decreased bycatch of non-target species and undersized individuals (Cooke et al. 2005; Cerdà et al. 2010; Garner et al. 2014).

Further work will be necessary to understand the influence of individual skill in determining the degree to which anglers could use self-releasing hooks to land and handlingfree release their targeted fish. Angler proficiency appeared necessary both for keeping tension on the line in order to retrieve the fish, as well as for letting go of that tension to allow the hook to self-release, as demonstrated in the videos where the fish is successfully and unsuccessfully released (see Methods). In another hook study that was also conducted in coastal northwestern Florida, Schaeffer and Hoffman (2002) found that volunteer anglers using barbless hooks landed significantly fewer fish $(22 \%)$ compared to using barbed hooks. Our study, in contrast, used standardized and experienced anglers, and our results indicated that there was no discernable difference in landing success between barbless or standard hooks. Differences in angling technique and experience may help explain the conflicting results reported from capture efficiency studies of barbed versus barbless hooks (e.g., Butler and Loeffel 1972; Muoneke and Childress 1994; Cooke et al. 2001; Schaeffer and Hoffman 2002; Cooke and Suski 2005; Bloom 2013), suggesting that angler skill may need to be considered for bite-shortened hooks.
The potential benefits from self-releasing hooks will largely depend on angler adoption (Crandall et al. 2018; Murphy et al. 2019; Garner et al. 2020), that, in turn, will depend on the degree to which self-releasing hooks can provide a quality recreational experience. Self-releasing hooks may invariably preclude the opportunity for anglers to photograph their catch, which could deter anglers from using them. Further, the bite-shortened hook had slightly higher unintended fish loss compared to the standard hook ( $9 \%$ vs. $1 \%$ overall). This difference was relatively small (2\% difference) between large-category fish, but greater for small fish (14\% with biteshortened hooks versus $4 \%$ with the standard hooks). While the logistic model indicated that these differences were not statistically strong, any conspicuous difference may be meaningful by anglers. The willingness for users to consider novel gear will likely vary considerably between target fish species, its conservation status, and, ultimately, the motivations of anglers in that fishery. For example, we would reason that tournament bass anglers will be more sensitive to and dissatisfied with any decline in landing success (Wilde et al. 1998; Arlinghaus 2006), and, furthermore, that there likely would lack strong conservation case that using self-releasing hooks is needed in such a fishery (Allen et al. 2008). However, anglers targeting highly valued and at risk species - such as Tarpon Megalops atlanticus (Adams et al. 2014), Bonefish Albula vulpes (Santos et al. 2017), Butterfly Peacock Bass Cichla ocellaris (Holley et al. 2008), Taimen Hucho taimen (Golden et al. 2019), or tunas and billfishes (Pons et al. 2017) — may be more willing to change their fishing gears and practices. Angler preferences in these "high-threshold," "bucket-list" sport fisheries are often willing to trade higher catch rates in favor fewer, higherquality trophy-sized fish (Golden et al. 2019). Conservation ethics are similarly demonstrated from a general willingness of catch-and-release anglers to socially sanction poor fishing practices (Guckian et al. 2018) as well as the collective action and lobby efforts demonstrated by their organizations to initiate and enact conservation policies (Danylchuck and Cooke 2011; Cooke et al. 2016; Danylchuk et al. 2018).

With further validation and understanding, prescriptive hook gear regulations could provide a management tool to effectively lower fishing mortality that may be better received by fishers compared to traditional regulatory mechanisms, e.g., effort controls, harvest quotas, size limits, or seasonal closures. Specific, forseeable use cases for self-releasing hooks could be to allow restricted fishing in sensitive fishing areas, fisheries experiencing unsustainable fishing pressure, or notake aquatic protected areas. For example, Gude et al. (2012) posits that self-releasing hooks could allow catch-and-release

Table 3. Outputs of the selected landing success and hook self-release success generalized linear models (binomial with logit link) with effects of hook type and fish size. Odds ratio (log-transformed estimate) and hypothesis statistics ( $z$ - and $P$-values) for each factor level are relative to the logistic regression model intercept, i.e., the standard hook type and small fish size class.

\begin{tabular}{|c|c|c|c|c|c|}
\hline Model & Effect & Odds ratio & $95 \% \mathrm{Cl}$ & z-value & P-value \\
\hline \multirow[t]{4}{*}{ Landing success } & (Intercept) & & & 3.306 & 0.001 \\
\hline & Hook type: Barbless & 0.39 & $0.03-4.55$ & -0.751 & 0.453 \\
\hline & Hook type: Bite-shortened & 0.17 & $0.02-1.66$ & -1.518 & 0.129 \\
\hline & Fish size: Large & 14.50 & $1.69-124$ & 2.439 & 0.015 \\
\hline \multirow[t]{4}{*}{ Hook self-release success } & (Intercept) & & & -2.661 & 0.008 \\
\hline & Hook type: Barbless & 3.87 & $1.83-8.21$ & 3.53 & $<0.001$ \\
\hline & Hook type: Bite-shortened & 24.77 & $9.77-62.8$ & 6.76 & $<0.001$ \\
\hline & Fish size: Large & 0.49 & $0.24-1.01$ & -1.935 & 0.053 \\
\hline
\end{tabular}


(A) Landing success

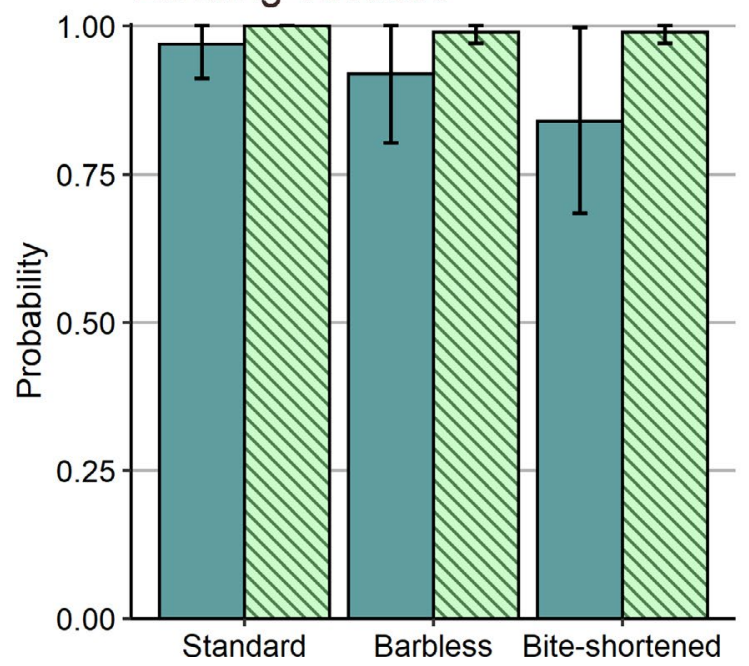

(B) Hook self-release success

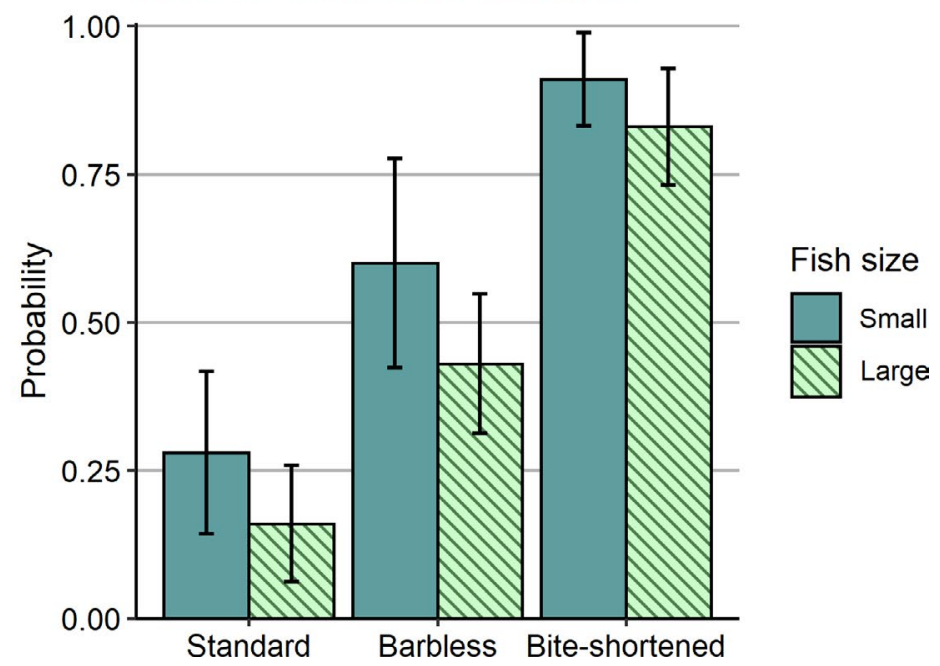

Figure 2. Mean probability for success $( \pm 95 \% \mathrm{CI}$ ) that Spotted Seatrout were (A) landed boatside and (B) self-released in the water without handling. Confidence intervals around the means were estimated from logistic generalized linear models (logitlinked) given the effects of hook type + fish size, which tested the differences between means for hook type (standard, barbless, and bite-shorted) and fish size (small $\leq 330 \mathrm{~mm}$ and large $>330 \mathrm{~mm}$ ).

fishing in the Palmyra Atoll National Wildlife Refuge, where there is a high risk of predation by sharks on released fish. Spatial management utilizing aquatic protected areas has shown substantial promise for protecting and restoring fish stocks and biodiversity (e.g., Lubchenco et al. 2003; Gaines et al. 2010; Edgar et al. 2014), but their implementation and enforcement can also create controversy among fishers and antagonism towards managers (Hannesson 1998; Hilborn et al. 2004). The potential compatibility of catch-and-release fishing with aquatic protected areas is indeed a field of developing research (Bartholomew and Bohnsack 2005; Sale et al. 2005; Danylchuck and Cooke 2011). Policies that could allow fishing access with self-releasing hooks in no-take protected areas could mitigate disenfranchisement caused by management imposed reductions in fishing rights. Such a regulatory paradigm may offer higher resolution options for stakeholders and managers to find comprise between a "black-and-white" choice of whether to allow fishing or not within the protected area. Careful implementation of such a management regime would need to consider the potential for predator-driven mortality after release (Raby et al. 2013) as well as possible sublethal effects that catch-and-self-release fishing could have on fish behavior, condition, or reproduction (Bartholomew and Bohnsack 2005). Assurance of user compliance would require dedicated two-way communication between managers and fishers, considering that fisher representation, engagement, and enforcement are often key determinants to the success of aquatic protected areas (Di Franco et al. 2016).

\section{CONCLUSION}

We found that a simple bite-shortened modified hook allowed anglers to release fish without handling them and thus obviate possible injuries from air exposure or contact with hands and nets. Smaller fish, which are often protected in length-regulated fisheries, were able to be handling-free released at higher rates. Our results also indicated that these self-releasing hooks may allow for a satisfactory recreational angling experience given that they had similar size selection and landing success rates compared to the unmodified hook. Although promising, these initial results indicate further research is needed to answer critical questions concerning the potential efficacy and implementation of using a novel hook gear: e.g., Would this work for other species? Are there other modifications that should be considered? Can a diversity of anglers with different experience levels have similar success? Would anglers adopt these hooks and be willingly to participate in handling-free recreational fisheries? and, Could self-releasing hooks provide a useful management and conservation tool? Such research appears warranted, given the continuing rise in worldwide recreational fishing and our improving understanding of discard effects in fisheries. With further study and application, innovative fishing gears and gear-use regulatory strategies may provide novel management approaches and fishing best practices to optimize the tradeoffs between allowing fishing opportunities and conserving fish populations.

\section{ACKNOWLEDGMENTS}

We thank Emily Colson (University of Florida) for help with graphic and media production, Kydd Pollock (The Nature Conservancy) for help with hook design, Larry Woodward (U.S. Fish and Wildlife Service) for operational support, and Justin Procopio (U.S. Geological Survey) for help with data collection. Pre-submission reviews were provided by Alexander Fogg (Okaloosa County), Alexandria Tucker (University of Florida), and Jordanna Bergman (Carleton University). Findings and conclusions in this article are those of the authors and do not necessarily represent the views of the University of Florida, the U.S. Fish and Wildlife Service, or any other affiliated institutions. We thank the anonymous reviewers and the Science Editor at Fisheries, Andy Danylchuk, for their comments that helped improve this manuscript. There is no conflict of interest declared in this article.

ORCID

Holden E. Harris (iD https://orcid.org/0000-0002-0486-2439 


\section{REFERENCES}

Adams. A. J., A. Z. Horodysky, R. S. Mcbride, K. Guindon, J. Shenker, T. C. Macdonald, H. D. Harwell, R. Ward, and K. Carpenter. 2014. Global conservation status and research needs for tarpons (Megalopidae), ladyfishes (Elopidae) and bonefishes (Albulidae). Fish and Fisheries 15:280-311.

Ahrens, R. N. M., M. S. Allen, C. Walters, and R. Arlinghaus. 2020. Saving large fish through harvest slots outperforms the classical minimumlength limit when the aim is to achieve multiple harvest and catchrelated fisheries objectives. Fish and Fisheries 21:483-510.

Akaike, H. 1974. A new look at the statistical model identification. IEEE Transactions on Automatic Control 19:716-723.

Allen, M. S., R. N. M. Ahrens, M. J. Hansen, and R. Arlinghaus. 2013. Dynamic angling effort influences the value of minimum-length limits to prevent recruitment overfishing. Fisheries Management and Ecology 20(2-3):247-257.

Allen, M. S., C. J. Walters, and R. Myers. 2008. Temporal trends in Largemouth Bass mortality, with fishery implications. North American Journal of Fisheries Management 28:418-427.

Alós, J., M. Palmer, A. M. Grau, and S. Deudero. 2008. Effects of hook size and barbless hooks on hooking injury, catch per unit effort, and fish size in a mixed-species recreational fishery in the western Mediterranean Sea. ICES Journal of Marine Science 65:899-905.

Arlinghaus, R. 2006. On the apparently striking disconnect between motivation and satisfaction in recreational fishing: the case of catch orientation of German anglers. North American Journal of Fisheries Management 26:592-605.

Arlinghaus, R., S. J. Cooke, J. Lyman, D. Policansky, A. Schwab, C. Suski, S. G. Sutton, and E. B. Thorstad. 2007. Understanding the complexity of catch-and-release in recreational fishing: an integrative synthesis of global knowledge from historical, ethical, social, and biological perspectives. Reviews in Fisheries Science 15(1-2):75-167.

Barthel, B. L., S. J. Cooke, C. D. Suski, and D. P. Philipp. 2003. Effects of landing net mesh type on injury and mortality in a freshwater recreational fishery. Fisheries Research 63:275-282.

Bartholomew, A., and J. A. Bohnsack. 2005. A review of catch-and-release angling mortality with implications for no-take reserves. Reviews in Fish Biology and Fisheries 15(1-2):129-154.

Bates, D., M. Mächler, B. Bolker, and S. Walker. 2015. Fitting linear mixedeffects models using Ime4. Journal of Statistical Software. Available https://bit.ly/3mzODR4

Bloom, R. K. 2013. Capture efficiency of barbed versus barbless artificial flies for trout. North American Journal of Fisheries Management 33:493-498.

Bohaboy, E. C., T. L. Guttridge, N. Hammerschlag, M. P. M. Van Zinnicq Bergmann, and W. F. Patterson. 2019. Application of threedimensional acoustic telemetry to assess the effects of rapid recompression on reef fish discard mortality. ICES Journal of Marine Science 77:83-96.

Bolker, B. M. 2007. Ecological models and data in R. Princeton University Press, Princeton, New Jersey.

Brownscombe, J. W., A. J. Danylchuk, J. M. Chapman, L. F. G. Gutowsky, and S. J. Cooke. 2017. Best practices for catch-and-release recreationa fisheries - angling tools and tactics. Fisheries Research 186:693-705.

Burnham, K. P. 2002. Model selection and multi-model inference: a practical information-theoretic approach, 2nd edition. Springer, New York.

Butler, J. A., and R. E. Loeffel. 1972. Experimental use of barbless hooks in Oregon's troll salmon fishery. Page Pacific Marine Fisheries Commission Bulletin, Portland, Oregon.

Cerdà, M., J. Alós, M. Palmer, A. M. Grau, and F. Riera. 2010. Managing recreational fisheries through gear restrictions: the case of limiting hook size in the recreational fishery from the Balearic Islands (NW Mediterranean). Fisheries Research 101:146-155.

Coggins, L. G., M. J. Catalano, M. S. Allen, W. E. Pine, and C. J. Walters. 2007. Effects of cryptic mortality and the hidden costs of using length limits in fishery management. Fish and Fisheries 8:196-210.

Colotelo, A. H., and S. J. Cooke. 2011. Evaluation of common anglinginduced sources of epithelial damage for popular freshwater sport fish using fluorescein. Fisheries Research 109(2-3):217-224.

Cook, K. V., R. J. Lennox, S. G. Hinch, and S. J. Cooke. 2015. Fish out of water: how much air is too much? Fisheries 40:452-461.

Cooke, S. J., B. L. Barthel, C. D. Suski, M. J. Siepker, and D. P. Philipp. 2005. Influence of circle hook size on hooking efficiency, injury, and size selectivity of Bluegill with comments on circle hook conservation benefits in recreational fisheries. North American Journal of Fisheries Management 25:211-219.

Cooke, S. J., and I. G. Cowx. 2004. The role of recreational fishing in global fish crises. BioScience 54:857.

Cooke, S. J., A. J. Danylchuk, S. E. Danylchuk, C. D. Suski, and T. L. Goldberg. 2006. Is catch-and-release recreational angling compatible with no-take marine protected areas? Ocean and Coastal Management 49(5-6):342-354.

Cooke, S. J., M. R. Donaldson, C. M. O'Connor, G. D. Raby, R. Arlinghaus, A. J. Danylchuk, K. C. Hanson, S. G. Hinch, T. D. Clark, D. A. Patterson, and C. D. Suski. 2013. The physiological consequences of catch-andrelease angling: perspectives on experimental design, interpretation, extrapolation and relevance to stakeholders. Fisheries Management and Ecology 20(2-3):268-287.

Cooke, S. J., Z. S. Hogan, P. A. Butcher, M. J. W. Stokesbury, R. Raghavan, A. J. Gallagher, N. Hammerschlag, and A. J. Danylchuk. 2016. Angling for endangered fish: conservation problem or conservation action? Fish and Fisheries 17:249-265.

Cooke, S. J., D. P. Philipp, K. M. Dunmall, and J. F. Schreer. 2001. The influence of terminal tackle on injury, handling time, and cardiac disturbance of Rock Bass. North American Journal of Fisheries Management 21:333-342

Cooke, S. J., and H. L. Schramm. 2007. Catch-and-release science and its application to conservation and management of recreational fisheries. Fisheries Management and Ecology 14:73-79.

Cooke, S. J., and C. D. Suski. 2005. Do we need species-specific guidelines for catch-and-release recreational angling to effectively conserve diverse fishery resources? Biodiversity and Conservation 14:1195-1209.

Crandall, C. A., M. Monroe, J. Dutka-Gianelli, B. Fitzgerald, and K. Lorenzen. 2018. How to bait the hook: identifying what motivates anglers to participate in a volunteer angler data program. Fisheries 43:517-526.

Danylchuck, A. J., and S. J. Cooke. 2011. Engaging the recreational angling community to implement and manage aquatic protected areas. Conservation Biology 25:458-464.

Danylchuk, A. J., A. Adams, S. J. Cooke, and C. D. Suski. 2008. An evaluation of the injury and short-term survival of bonefish (Albula spp.) as influenced by a mechanical lip-gripping device used by recreational anglers. Fisheries Research 93(1-2):248-252.

Danylchuk, A. J., S. C. Danylchuk, A. Kosiarski, S. J. Cooke, and B. Huskey. 2018. Keepemwet Fishing-an emerging social brand for disseminating best practices for catch-and-release in recreational fisheries. Fisheries Research 205:52-56

Davis, M. W. 2002. Key principles for understanding fish bycatch discard mortality. Canadian Journal of Fisheries and Aquatic Sciences 59:1834-1843.

Di Franco, A., P. Thiriet, G. Di Carlo, C. Dimitriadis, P. Francour, N. L. Gutiérrez, A. Jeudy De Grissac, D. Koutsoubas, M. Milazzo, M. D. M. Otero, C. Piante, J. Plass-Johnson, S. Sainz-Trapaga, L. Santarossa, S. Tudela, and P. Guidetti. 2016. Five key attributes can increase marine protected areas performance for small-scale fisheries management. Scientific Reports 6:1-9.

Dunn, P. K., and G. K. Smyth. 2018. Linear regression models. Page 562 in R. De Veaux, S. E. Fienberg, and I. Olkin, editors. Generalized linear models with examples in R. Springer Texts in Statistics, New York

Edgar, G. J., R. D. Stuart-Smith, T. J. Willis, S. Kininmonth, S. C. Baker, S. Banks, N. S. Barrett, M. A. Becerro, A. T. F. Bernard, J. Berkhout, C. D. Buxton, S. J. Campbell, A. T. Cooper, M. Davey, S. C. Edgar, G. Försterra, D. E. Galván, A. J. Irigoyen, D. J. Kushner, R. Moura, P. E. Parnell, N. T. Shears, G. Soler, E. M. A. Strain, and R. J. Thomson. 2014 Global conservation outcomes depend on marine protected areas with five key features. Nature 506:216-220.

Ferguson, R. A., and B. L. Tufts. 1992. Physiological effects of brief air exposure in exhaustively exercised Rainbow Trout ( Oncorhynchus mykiss): implications for "catch and release" fisheries. Canadian Journal of Fisheries and Aquatic Sciences 49:1157-1162.

Gaines, S. D., C. White, M. H. Carr, and S. R. Palumbi. 2010. Designing marine reserve networks for both conservation and fisheries management. Proceedings of the National Academy of Sciences of the United States of America 107:18286-18293.

Garner, S. B., W. F. Patterson III, C. E. Porch, and J. H. Tarnecki. 2014 Experimental assessment of circle hook performance and selectivity in the northern Gulf of Mexico recreational reef fish fishery. Marine and Coastal Fisheries 6:235-246. 
Garner, S. B., W. F. PattersonIII, and C. E. Porch. 2017. Experimental assessment of circle vs. J hook performance and selectivity in the northern Gulf of Mexico recreational reef fish fishery. ICES Journal of Marine Science 74:1437-1447.

Garner, S. B., W. F. Patterson III, J. F. Walter, and C. E. Porch. 2020 Simulating effects of hook-size regulations on recreational harvest efficiency in the northern Gulf of Mexico Red Snapper fishery. Fisheries Research 228:105561.

Golden, A. S., C. M. Free, and O. P. Jensen. 2019. Angler preferences and satisfaction in a high-threshold bucket-list recreational fishery. Fisheries Research 220:105364.

Guckian, M. L., A. J. Danylchuk, S. J. Cooke, and E. M. Markowitz. 2018. Peer pressure on the riverbank: assessing catch-and-release anglers' willingness to sanction others' (bad) behavior. Journal of Environmental Management 219:252-259.

Gude, A., K. Pollock, and A. Meyer. 2012. Modification of a standard Jhook design allowing self-release of fish and reducing mortality risks in caught fish. International Symposium on Circle Hooks in Research, Management, and Conservation-Abstracts. Bulletin of Marine Science 88:791-815.

Hannan, K. D., Z. C. Zuckerman, C. R. Haak, and A. D. Shultz. 2015. Impacts of sun protection on feeding behavior and mucus removal of Bonefish, Albula vulpes. Environmental Biology of Fishes 98:2297-2304.

Hannesson, R. 1998. Marine reserves: what would they accomplish? Marine Resource Economics 13:159-170.

Hilborn, R., K. Stokes, J. J. Maguire, T. Smith, L. W. Botsford, M. Mangel, J. Orensanz, A. Parma, J. Rice, J. Bell, K. L. Cochrane, S. Garcia, S. J. Hall, G. P. Kirkwood, K. Sainsbury, G. Stefansson, and C. Walters. 2004. When can marine reserves improve fisheries management? Ocean and Coastal Management 47(3-4):197-205.

Holley, M. H., M. J. Maceina, M. Thomé-Souza, and B. R. Forsberg. 2008. Analysis of the trophy sport fishery for the Speckled Peacock Bass in the Rio Negro River, Brazil. Fisheries Management and Ecology 15:93-98.

Kostecki, P. T., P. Clifford, S. P. Gloss, and J. C. Carlisle. 1987. Scale loss and survival in smolts of Atlantic Salmon (Salmo Salar) after turbin passage. Canadian Journal of Fisheries and Aquatic Sciences 44:210-214.

Lubchenco, J., S. R. Palumbi, S. D. Gaines, and S. Andelman. 2003. Plugging a hole in the ocean: the emerging science of marine reserves. Ecological Applications 13(1 SUPPL.):S3-S7.

Muoneke, M. I., and W. M. Childress. 1994. Hooking mortality: a review for recreational fisheries. Reviews in Fisheries Science 2:123-156.

Murphy, R., S. Scyphers, S. Gray, and J. H. Grabowski. 2019. Angler attitudes explain disparate behavioral reactions to fishery regulations. Fisheries 44:475-487.

Nilsson, P. A., and C. Brönmark. 2000. Prey vulnerability to a gape-size limited predator: behavioural and morphological impacts on northern pike piscivory. Oikos 88:539-546.

Ostrand, K. G., M. J. Siepker, S. J. Cooke, W. F. Bauer, and D. H. Wahl. 2005. Largemouth Bass catch rates and injury associated with non-offset and offset circle hook configurations. Fisheries Research 74(1-3):306-311

Pollock, K. H., and W. E. Pine. 2007. The design and analysis of field studies to estimate catch-and-release mortality. Fisheries Management and Ecology 14:123-130.

Pons, M., T. A. Branch, M. C. Melnychuk, O. P. Jensen, J. Brodziak, J. M. Fromentin, S. J. Harley, A. C. Haynie, L. T. Kell, M. N. Maunder, A. M. Parma, V. R. Restrepo, R. Sharma, R. Ahrens, and R. Hilborn. 2017. Effects of biological, economic and management factors on tuna and billfish stock status. Fish and Fisheries 18:1-21.

Prince, J., and A. Hordyk. 2019. What to do when you have almost nothing: a simple quantitative prescription for managing extremely datapoor fisheries. Fish and Fisheries 20:224-238.

R Core Team. 2021. R: a language and environment for statistical computing. R Foundation for Statistical Computing, Vienna.

Raby, G. D., J. R. Packer, A. J. Danylchuk, and S. J. Cooke. 2013. The understudied and underappreciated role of predation in the mortality of fish released from fishing gears. Fish and Fisheries 15:489-505.

Sale, P. F., R. K. Cowen, B. S. Danilowicz, G. P. Jones, J. P. Kritzer, K. C. Lindeman, S. Planes, N. V. C. Polunin, G. R. Russ, Y. J. Sadovy, and R. S. Steneck. 2005. Critical science gaps impede use of no-take fishery reserves. Trends in Ecology and Evolution 20:74-80.

Santos, R. O., J. S. Rehage, A. J. Adams, B. D. Black, J. Osborne, and E. K. N. Kroloff. 2017. Quantitative assessment of a data-limited recreational bonefish fishery using a time-series of fishing guides reports. PLoS One 12:e0184776.

Sauls, B., and O. Ayala. 2012. Circle hook requirements in the Gulf of Mexico: application in recreational fisheries and effectiveness for conservation of reef fishes. Bulletin of Marine Science 88:667-679.

Schaeffer, J. S., and E. M. Hoffman. 2002. Performance of barbed and barbless hooks in a marine recreational fishery. North American Journal of Fisheries Management 22:229-235.

Stalhammar, M., T. Franstam, J. Lindstrom, J. Hojesjö, R. Arlinghaus, and P. A. Nilsson. 2014. Effects of lure type, fish size and water temperature on hooking location and bleeding in Northern Pike (Esox lucius) angled in the Baltic Sea. Fisheries Research 157:164-169.

Wilde, G. R., K. L. Pope, and B. W. Durham. 2003. Lure-size restrictions in recreational fisheries. Fisheries 28:18-26.

Wilde, G. R., R. K. Riechers, and R. B. Ditton. 1998. Differences in attitudes, fishing motives, and demographic characteristics between tournament and nontournament black bass anglers in Texas. North American Journal of Fisheries Management 18:422-431.

SUPPORTING INFORMATION

Additional supplemental material may be found online in the Supporting Information section at the end of the article. Supplementary Material AFS 